\title{
Nutrition and sensory evaluation of germinated legumes
}

\author{
Karin Viktorinová ${ }^{1}$, Karin Petřeková ${ }^{1}$, Jaroslav Šimek ${ }^{3,1}$, Ivo Hartman ${ }^{2,1}$, Vítězslav Hertel ${ }^{3}$ \\ 1 Department of Physiology and Pathophysiology, \\ Faculty of Medicine, University of Ostrava, Syllabova 19, \\ 70300 Ostrava-Vitkovice, Czech Republic \\ 2 Research Institute of Brewing and Malting, Mostecká 971/7, \\ 61400 Brno, Czech Republic \\ 3 SEMIX PLUSO, spol. s.r.o, Rybničky 338, 74781 Otice,
Czech Republic \\ *corresponding author: karin.petrekova@osu.cz
}

\section{ABSTRACT}

This study aims to compare the nutritional, functional and sensory properties of red lentils (Lens culinaris Medic.) and black beans (Phaseolus vulgaris L.). The input material was raw seeds of both kinds of legumes, which were subjected to a germination process under defined conditions and subsequently processed into a form of dried flakes. Basic nutritional parameters supplemented with determination of phytic acid, methionine and antioxidant activity were assayed in samples of non-germinated seeds and final products. Both final products obtained by germination and subsequent drying of legumes exhibited increase in energy, mainly in connection with increase in carbohydrate values. The content of fats and sugars did not change significantly. Saturated fatty acids increased significantly in germinated bean flakes, however, their value in the product is low, similar to red lentil chips. Also, legumes are a good source of protein and fibre. We also found a similar trend in the red lentil flakes and the black bean flakes. Both their protein content and amount of methionine together with fibre increased significantly. The decrease in antioxidant activity values was probably due to the thermal stress of the germinated seeds during steam stabilization and subsequent drying. Drying is a suitable way of preserving germinated seeds. Due to the effect of higher temperatures during the drying of germinated seeds, there are not only nutritional changes, but also sensory changes. By reducing the water content, the seeds acquire a brittle structure and are more easily digested. In our survey, sensory evaluation classed the product made of germinated red lentils as better than that of black beans.

Keywords: germination, legumes, red lentils, black beans

\section{Introduction}

Legumes offer many nutritional benefits and therefore should be consumed abundantly. Legume consumption is very low in Northern European countries. Although more types of legumes are available for human nutrition, only some of them are used in larger quantities. Among the most produced and therefore often consumed legumes are beans, chickpeas and peas. Less common legumes, including other colour varieties of such traditional species as red and black lentils or black beans, show a great potential for development of novel food products due to their good nutritional composition and rich functional properties (Schoenlechner, 2016).
Legume seeds are a very rich source of many nutritionally beneficial substances. In addition to their high protein content, they are a source of hydrophilic vitamins (especially B-group vitamins), minerals (potassium, calcium, phosphorus, iron or zinc) and fiber (Dostálová et al., 2016).

The use of legumes in the food industry is being investigated. This is because much of modern food production relies on the use of animal proteins. However, the changing market in recent years has seen an increase in the sale of plant protein products as a result of economic and environmental concerns of consumers. Because proteins in lentils have a high lysine content, they can
Research Institute of Brewing and Malting, Plc. Published online: 15 June 2020 
also satisfy full nutritional requirements when incorporated into cereal-based products or in combination with cereal proteins that contain an adequate amount of sulphur-containing amino acids (Jarpa-Parra, 2018).

However, it should be noted that legumes also contain antinutritional substances. These include $\alpha$-galactosides or phytic acid. $\alpha$-Galactosides cause unpleasant flatulence whereas phytic acid forms insoluble salts, e.g. with zinc or iron, which results in a lower bioavailability of the minerals (Dostálová et al., 2016). The content and effect of antinutritional agents can be reduced by appropriate treatment, such as germination, fermentation, but also soaking before heat treatment (Saratu and Matthew, 2011).

Available studies have shown that germination can give rise not only to a partial removal of antinutritional substances, but also to an increase in the content of protective substances. Soaking legume seeds as part of the germination process makes legumes more digestible, removing some phytates and tannins, which are responsible for the reduced availability of legume nutrients.

Beans contain complex sugars called oligosaccharides. The human body does not produce any enzyme that naturally cleaves these sugars. Therefore, oligosaccharides are fermented in the colon. This process produces methane, causing bloating and other unpleasant digestive problems. Soaking beans in water and sufficient heat treatment can significantly reduce the amount of oligosaccharides in beans that are difficult to digest (Augustin et al., 1981).

Moslem et al. (2016) reported that germination of red lentil for 48 hours and $25{ }^{\circ} \mathrm{C}$ caused a significant increase in protein, calcium or phosphorus. On the other hand, after germination, the red lentil contained less lipids, iron and zinc.

Ma et al. (2018) presented nutritional data of germinated yellow pea. Yellow pea sown after germination (72 hours at $30{ }^{\circ} \mathrm{C}$ ) contained a higher percentage of proteins, including a slight increase in the content of the essential amino acid methionine. The content of carbohydrates and fibre also increased while the content of tannins, which belong to antinutritional substances, was reduced.

A study of Vigna sinensis again confirmed that germination is a relatively effective method for removing antinutritional substances without the use of heat treatment, which can significantly reduce the content of the so-called thermolabile nutrients. The best results were obtained with a 24 -hour germination at $25{ }^{\circ} \mathrm{C}$. The content of phytic acid decreased 4-16×, depending on the sample type. Fat and carbohydrates also decreased. Protein increased by $9-12 \%$ and vitamin C increased $4-38 \times$ (Devi et al., 2015).
The nutritional benefit of germination is predominantly due to an increase in protein or fibre and reduction of the fat. The increase in protein is attributed to protein synthesis in the germination process and reduction of the fat content by the metabolic activity of the seeds (Saratu and Matthew, 2011). Germination of legumes can bring about significant biochemical and nutritional changes that can be beneficial to our health and overall nutritional status. Germination is a natural process in which a germ grows from the seed of a plant. Before germination seeds go through a period of rest, which is important in terms of overcoming unfavourable conditions. Under favourable conditions, a seed begins to germinate and develops into a plant (Rusydi and Azrina, 2012).

In addition to mung beans, also black beans, red lentils, yellow peas or adzuki beans are suitable for germination (Abbas and Ahmad, 2018; Bretherton 2018; Jirková, 2016; Galchus, 2014).

The aim of our study was to determine, analyse and compare the main nutritional parameters for input of raw seeds from selected pulses and germinated final products obtained from these raw materials. The aim of sensory evaluation of germinated final legume products was to gain independent information about their sensory properties. Subsequently, we aimed to determine whether the germination and subsequent drying of red lentils and black beans will significantly affect the nutritional values of the final products, contribute to their better digestibility and whether these alternative products can be palatable to consumers.

\section{Materials and Methods}

The initial material for our study was seed samples of red lentils (Lens culinaris Medic.) and black beans (Phaseolus vulgaris L.) From both legume commodities, 3 samples were taken at the inlet and then 3 germinated samples after the processing, i.e. after stabilization by steam, pressing and drying. The samples were labelled and sent for analysis.

\subsection{Soaking, germination and processing}

The germination and processing of leguminous seeds took place in production hall 02 of the company SEMIX PLUSO, spol. s r.o.

The grains were soaked for a specified time (Table 1), then sprayed onto a germination floor and germination was carried out for a defined time (Table 1). The temperature in the germination was $16-18{ }^{\circ} \mathrm{C}$. After the germination, the seeds were further processed, i.e. stabilized by steam and dried to the level of storable dry matter, i.e. 
Table 1 Processing of raw materials into final products

\begin{tabular}{|c|c|c|c|c|}
\hline Feedstock & Soaking time $(\mathrm{h})$ & Germination time $(\mathrm{h})$ & Processing & Final product \\
\hline Red lentil & 6 & $28-32$ & Steam stabilization, pressing, drying & Germinated red lentil flakes \\
\hline Black beans & 8 & $28-32$ & Steam stabilization, pressing, drying & Germinated black bean flakes \\
\hline
\end{tabular}

to final products (Table 1). The final legume products were germinated red lentils in a form of flakes (Figure 1) and germinated black beans also in a form of flakes (Figure 2).

\subsection{Microbiological analysis}

Determination of selected microbiological parameters (E. coli, enterobacteria, moulds) was performed by culture methods according to valid standards. Enterobacteriaceae - ISO 21528-2 (2018); E. coli - ISO 16649-2 (2001); Moulds - ISO 21527-2 (2008).

\subsection{Germination tests}

Seed germination was determined by soaking the seeds in a solution of hydrogen peroxide at room temperature. After 72 hours, the non-germinated seeds were separated and germination degree was calculated. To determine the percentage of germination, the seeds were germinated on a wet filter paper on Petri dishes at room temperature for 72 hours. Germinated seeds were separated every $24 \mathrm{~h}$.

\subsection{Biochemical and nutritional parameters}

The nutritional values (energy, fat, saturated fatty acids, carbohydrates, sugars, fibre, proteins) were analysed according to the requirements of Regulation (EU) No 1169/2011 of the European Parliament and European Council. The analyses were performed by EUROFINS CZ, Ltd. The content of phytic acid in samples after extraction with hydrochloric acid was determined by capillary isotachophoresis (Kvasnička et al., 2011).

Methionine was first oxidized by a mixture of formic acid and hydrogen peroxide and then hydrolysed by hydrochloric acid. Its content was determined by ion chromatography with post-column derivatization with ninhydrin (ÚKZUZ, 2019).

The antioxidant activity of DPPH was determined by the reaction of the test substance with the stable radical diphenylpicrylhydrazyl (DPPH), which reduces the radical to form diphenyl picrylhydrazine. The reaction is monitored spectrophotometrically at $517 \mathrm{~nm}$ (Benzie and Strain, 1999).

The antioxidant activity was measured by the FRAP assay based on the reduction of trivalent iron complex with 2,4,6-tri(2-pyridyl-1,3,5-triazine) ( $\mathrm{Fe}^{3+}$-TPTZ) by

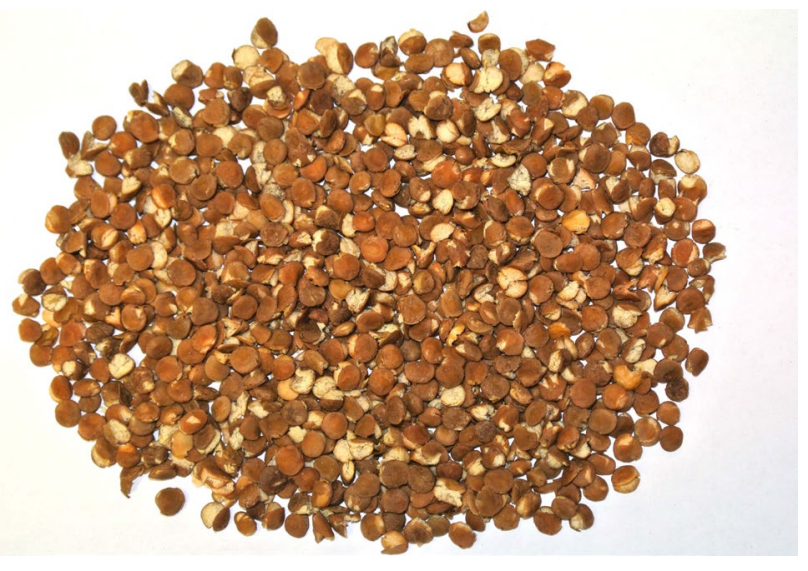

Figure 1 Germinated red lentil flakes

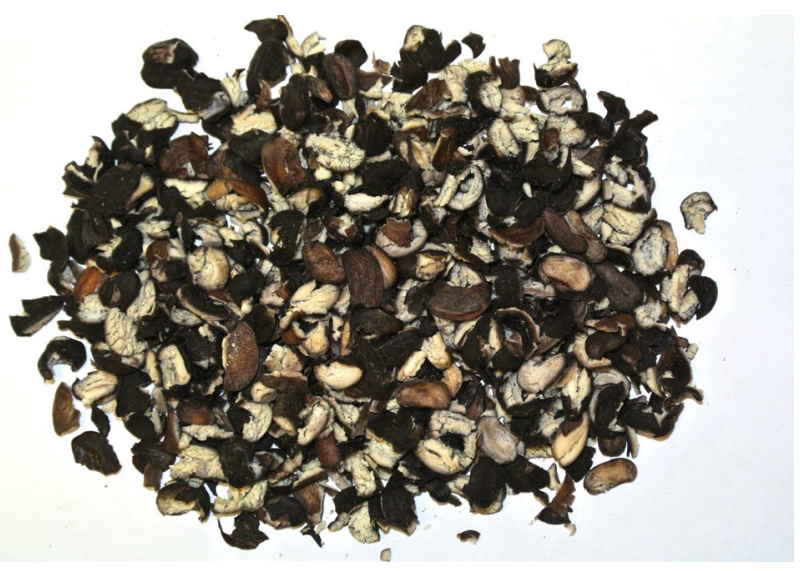

Figure 2 Germinated black flakes

the antioxidants from the samples. The increase in absorbance at $593 \mathrm{~nm}$ corresponding to the $\mathrm{Fe}^{2+}$-TPTZ complex is a measure of antioxidant activity (Benzie and Strain, 1999).

\subsection{Sensory analysis}

A panel of 12 trained tasters from the Research Institute of Brewing and Malting, Prague, and 22 untrained tasters, lay evaluators from RIBM Brno, performed the sensory evaluation of the final legume products. The sensory evaluation parameters were colour, appearance, smell - pleasantness, intensity, crispness, structure, taste - pleasantness, intensity, salty taste, sweet taste, bitter taste - and overall impression.

The evaluators received samples in encoded containers and evaluated selected descriptors on a graphical 
scale. Water was administered as a taste neutralizer. The overall ranking is based on a rank test, where samples were compared on a scale of 1-7, 1 - best, 7 - worst. If the order was the same, the next place remained vacant. The evaluation of partial parameters that more specifically reflect the sensory character of the product has been chosen on a scale of $1-5$, where 1 is the best, 5 is the worst/ serious defect.

\subsection{Statistical analysis}

The arithmetic mean and other characteristics (standard deviation, minimum and maximum values) were calculated from each series of measurements of the given commodity at the input and output ( 3 samples). The variation coefficient ( $v$ ) was calculated for each series of measurements. Input/output comparison was expressed as per cent change (arithmetic mean input/arithmetic mean output -1$) * 100 \%)$.

A paired t-test at a significance level of $5 \%$ was used for statistical evaluation of the change. MS Excel and Stata v. 14 were used to process the results.

\section{Study limits}

Each series contained only 3 measurements, so using a statistical test is problematic. Even in the case of a significant per cent change it is also necessary to look at the variability of the measurement, i.e. the variation coefficient. In the case of a large variability, a statistically insignificant difference may occur for a large per cent difference. It is also important to consider statistical and material significance.

\section{Results and Discussion}

There was a statistically significant increase of about $9.7 \%$ in the energy value $(\mathrm{p}=0.0106)$ of the germinated red lentil flakes; carbohydrates increased by $13.1 \%$ ( $p=0.0235)$, proteins by $10.1 \%(p=0.0359)$. Antioxidant activity (DPPH) decreased by $77.8 \%$ and (FRAP) by $65.4 \%$ (Table 2).

The germinated black bean flakes evinced a statistically significant increase of about $11.7 \%$ in the energy value $(\mathrm{p}=0.0043)$, saturated fatty acids increased by $131 \%$ ( $p=0.0022)$, fibre by $34.1 \%(p=0.0078)$, protein by $12 \%$ $(0.0002)$ and methionine by $14.4 \%(p=0.0192)$. Antioxidant activity (FRAP) decreased by $47.6 \%(\mathrm{p}=0.0017)$ (Table 2).

For both germinated legume products, the energy value increased compared to the input values. For a given commodity, an increase in the energy content is expected in the case of an increase in the content of energy sub-

Table 2 Analysis of nutritional parameters and antioxidant activity of germinated legume products

\begin{tabular}{|c|c|c|c|c|c|c|c|c|c|c|c|c|}
\hline & \multicolumn{6}{|c|}{ Red lentil/Germinated red lentil flakes } & \multicolumn{6}{|c|}{ Black beans/Germinated black bean flakes } \\
\hline & $\begin{array}{c}\text { input } \\
\text { (Mean } \pm \text { SD) }\end{array}$ & $\begin{array}{l}* v \\
(\%)\end{array}$ & $\begin{array}{c}\text { output } \\
\text { (Mean } \pm \text { SD) }\end{array}$ & $\begin{array}{l}* v \\
(\%)\end{array}$ & $\begin{array}{l}\text { Change } \\
\text { (\%) }\end{array}$ & $\mathrm{p}<0.05$ & $\begin{array}{c}\text { input } \\
\text { (Mean } \pm \text { SD) }\end{array}$ & $\begin{array}{l}* v \\
(\%)\end{array}$ & $\begin{array}{c}\text { output } \\
\text { (Mean } \pm \text { SD) }\end{array}$ & $\begin{array}{l}* v \\
(\%)\end{array}$ & $\begin{array}{c}\text { Change } \\
(\%)\end{array}$ & $\mathrm{p}<0.05$ \\
\hline Energy value $\mathrm{kJ} / 100 \mathrm{~g}$ & $1376.3 \pm 10.5$ & 0.8 & $1510.0 \pm 19.0$ & 1.3 & +9.7 & 0.0106 & $1279.7 \pm 10.4$ & 0.8 & $1430.0 \pm 13.5$ & 0.9 & +11.7 & 0.0043 \\
\hline Fat $\mathrm{g} / 100 \mathrm{~g}$ & $1.7 \pm 0.2$ & 9.4 & $1.5 \pm 0.3$ & 22.9 & -13.1 & 0.5029 & $2.1 \pm 0.1$ & 2.7 & $2.4 \pm 0.2$ & 10.4 & +14.4 & 0.2254 \\
\hline $\begin{array}{l}\text { of which saturated } \\
{ }^{*} \mathrm{FAg} / 100 \mathrm{~g}\end{array}$ & $0.2 \pm 0.0$ & 10.2 & $0.3 \pm 0.1$ & 39.2 & +26.2 & 0.5223 & $0.2 \pm 0.0$ & 3.0 & $0.4 \pm 0.0$ & 3.4 & +131.0 & 0.0022 \\
\hline $\begin{array}{l}\text { Carbohydrates } \\
\mathrm{g} / 100 \mathrm{~g}\end{array}$ & $46.1 \pm 0.1$ & 0.2 & $52.1 \pm 1.6$ & 3.0 & +13.1 & 0.0235 & $40.7 \pm 0.9$ & 2.2 & $43.2 \pm 0.6$ & 1.3 & +6.3 & 0.0554 \\
\hline $\begin{array}{l}\text { of which } \\
\text { sugars } \mathrm{g} / 100 \mathrm{~g}\end{array}$ & $1.7 \pm 0.1$ & 3.3 & $3.3 \pm 2.0$ & 58.9 & +92.3 & 0.4167 & $2.7 \pm 0.1$ & 2.1 & $2.5 \pm 0.2$ & 6.0 & -7.3 & 0.1835 \\
\hline Proteins g/100 g & $23.3 \pm 0.1$ & 0.5 & $25.6 \pm 0.7$ & 2.8 & +10.1 & 0.0359 & $21.0 \pm 0.0$ & 0.0 & $23.5 \pm 0.1$ & 0.2 & +12.0 & 0.0002 \\
\hline $\begin{array}{l}\text { Methionine } \mathrm{g} / 100 \mathrm{~g} \\
\text { dry matter }\end{array}$ & $1.8 \pm 0.0$ & 1.9 & $1.9 \pm 0.0$ & 0.6 & +5.3 & 0.0684 & $2.1 \pm 0.1$ & 2.3 & $2.5 \pm 0.0$ & 1.2 & +14.4 & 0.0192 \\
\hline $\begin{array}{l}\text { Phytic acid } \\
\text { g/kg dry matter }\end{array}$ & $8.6 \pm 0.2$ & 2.3 & $8.3 \pm 0.4$ & 4.6 & -3.9 & 0.4045 & $7.1 \pm 0.6$ & 9.1 & $7.6 \pm 0.5$ & 6.8 & +7.5 & 0.2997 \\
\hline $\begin{array}{l}\text { Antioxidant activity } \\
\text { (DPPH) \%/100 g }\end{array}$ & $34.9 \pm 2.8$ & 8.1 & $7.8 \pm 0.6$ & 7.2 & -77.8 & 0.0023 & $16.6 \pm 6.1$ & 36.5 & $6.3 \pm 0.6$ & 10.1 & -62.3 & 0.0973 \\
\hline $\begin{array}{l}\text { Antioxidant activity } \\
\text { (FRAP) \%/100 g }\end{array}$ & $16.3 \pm 0.2$ & 1.0 & $5.6 \pm 0.2$ & 3.1 & -65.4 & 0.0063 & $11.4 \pm 0.2$ & 1.3 & $6.0 \pm 0.3$ & 5.5 & -47.6 & 0.0017 \\
\hline
\end{tabular}

${ }^{*}$ v/coefficient of variation; FA/fatty acids 
strates. In our case, the content of carbohydrates and proteins in both products from the germinated legumes increased.

Fats did not show statistically significant changes in values. The content of saturated fatty acids was low. Saturated fatty acids in the germinated red lentil flakes made $0.8 \%$ and in the germinated black bean flakes $1.0 \%$ of the total energy per $100 \mathrm{~g}$ of product.

Germinated black bean flakes showed a significant increase in fibre, however, a slight increase, although statistically insignificant, was also measured in the germinated red lentil product. This finding corresponds to the results of Fouad and Rehab (2015), where the authors found an increase in crude fibre during lentil germination. The total fibre was very favourable for both final products, i.e. $16.8 \mathrm{~g}$ for the germinated red lentil flakes and $26.1 \mathrm{~g}$ for the germinated black bean flakes per $100 \mathrm{~g}$ of product.

The sugar content did not increase or decrease significantly. The germinated red lentil flakes showed a $92.3 \%$ increase in sugars, however, with regard to the set coefficient of variation, this increase is not statistically significant. The sugar content in relation to the total energy per $100 \mathrm{~g}$ of the products was very favourable, reaching $3.7 \%$ for the germinated red lentil flakes and $3 \%$ for the germinated black bean flakes. Sugars include all monosaccharides and disaccharides present in food, with the exception of polyalcohols, and their content in final products corresponds to recommended nutritional trends aimed at reducing sugar intake by a maximum of $5-10 \%$ of daily energy intake (Regulation (EU) No 1169/2011).

The protein content of both final germinated legume products increased significantly. Protein in the red lentils made $29 \%$ and in the germinated black beans $28 \%$ of the total energy per $100 \mathrm{~g}$ of the product. The essential amino acid levels of methionine increased significantly in the germinated black bean product. Thought insignificant, the increase in methionine content was also measured in the red lentils. Methionine is an essential amino acid that has been reported to be limited in legumes. Its content is lower in legumes compared to other essential amino acids. Increasing its content in germinated legume seeds is positive for their nutritional evaluation. Fouad and Rehab (2015) also report a statistically significant 7.3 to $12.6 \%$ increase in protein during lentil germination. They explain the increase in protein by the loss of dry weight of the seeds during germination or by the synthesis of enzymatically active proteins during seed germination, alternatively also by the change in composition after the degradation of other components. They also point to an increase in the bioavailability of amino acids from germinated legume seeds.

Antioxidant activity (DPPH, FRAP) decreased for both the germinated red lentils and (FRAP) germinated black bean products. The decrease in antioxidant activity could be caused by a thermal load of the products during the steam stabilization and subsequent drying.

The results of our research followed a similar trend to that noted by Moslem et al. (2016) or Ma et al. (2018). Protein, essential amino acid methionine, carbohydrates and fibre have increased in germinated legume products.

In contrast, compared to the results of Moslem et al. (2016), Ma et al. (2018), and Rusydi, Azrina (2012), who demonstrated that legume germination is an effective method in reducing phytic acid and tannin content. The phytic acid content of the final germinated red lentil product did not decrease significantly, but decreased compared to the results obtained in a germinated black bean product where there was an insignificant increase in the content of this anti-nutritive substance. This trend could be influenced by the final treatment of germinated legume seeds, i.e. by drying.

The panel of trained and untrained tasters evaluated the germinated red lentil flakes as best (trained tasters 2.0, untrained tasters 2.4). Both products were positively evaluated for their taste and crispness (Table 3).

The fragility and crunchiness of the evaluated products is given by their subsequent drying. Drying is a natural method of preservation in which water is removed and germinated seeds become very crunchy (Bretherton 2018; Galchus, 2014). 
Seed germination tests were carried out to verify the use of feedstock for the production of germinated products. The minimum germination was set at $85 \%$. Seed germination results were on average $98.7 \%$ for the red lentils and $89.7 \%$ for the black beans.

Microbiological analyses were performed to evaluate the entire production process, especially to control microbial contamination during the entire production process. Indicator microorganisms and moulds were determined. The results showed that microbial contamination of the final products is low and meets the requirements of ČSN 569609 (2008).

\section{Conclusion}

The results of our research provide interesting facts about selected nutritional changes in germinated red lentil and germinated black bean products. The final products have a nutritionally low fat content, a high proportion of protein and fibre, a favourable content of sugars and saturated fatty acids. The advantage of germinated versions of legumes is their better digestibility and tolerance by the consumer. From a practical point of view, germinated legumes treated by drying can be an alternative to the consumption of legumes and they contribute to increase in their consumption. Like legumes, germinated legume products are gluten-free and can be widely used by a group of consumers who prefer or must follow a gluten-free diet.

\section{Acknowledgement}

This publication was created in cooperation with the Institute of Physiology and Pathophysiology, University of Ostrava, Faculty of Medicine, Research Institute of Brewing and Malting, PLC. Brno and SEMIX PLUSO, spol. s r.o. Otice. Germinated seed products were developed by SEMIX PLUSO, spol. s r.o. under the subsidy title No. 17/005/16220/780/000054. Development of new products based on germinated pseudo-mobiles, cereals and legumes. The results of sensory evaluation and nutritional analyses of monitored samples were used within the project SGS SGS06/LF/2019-2020 Nutritional evaluation of cereals, pseudo-mobiles, legumes and products from these foods and their use in gluten-free diet.

\section{References}

Abbas, Y., Ahmad, A. (2018). Impact of processing on nutritional and antinutritional factors of legumes: A review. Annals. Food Science and Technology [online]. 19(2), 199-215 [cit. 2020-03-27]. ISSN
20652828. Available from: http://www.afst.valahia.ro/images/documente/2018/issue2/I.4_Abbas.pdf.

Augustin, J., Beck, C. B., Kalbfleish, G., Kagel, L. C., Matthews, R. H. (1981). Variation in the Vitamin and Mineral Content of Raw and Cooked Commercial Phaseolus Vulgaris Classes. Journal of Food Science, 46(6), 1701-1706. https://doi.org/10.1111/j.1365-2621.1981.tb04467.x.

Benzie, I. F. F., Strain, J. J. (1999). Ferric reducing/antioxidant power assay: Direct measure of total antioxidant activity of biological fluids and modified version for simultaneous measurement of total antioxidant power and ascorbic acid concentration. Methods in Enzymology, 299, 15-27. https://doi.org/10.1016/s0076-6879(99)99005-5

Bretherton, C. (2018). Naklíčeno!: semínka, obilniny a luštěniny. Praha: Euromedia. Esence. ISBN 978-80-7549-479-5.

ČSN 569609 (2008). Guides to good hygiene and manufacturing practice - Microbiological criteria for foods. Principles for the establishment and application. Available from: http://www.fao.org/3/y1579e/ y1579e04.htm

Devi, C.B., Kushwaha, A., Kumar, A. (2015). Sprouting characteristics and associated changes in nutritional composition of cowpea (Vigna unguiculata). Journal of Food Science \& Technology, 52(10), 68216827. https://doi.org/10.1007/s13197-015-1832-1

Dostálová, R., Horáček, J., Skřivan, P. (2016). Jak poznáme kvalitu? Obiloviny a luštěniny. Sdružení českých spotřebitelů, z. ú: Potravinářská komora ČR v Praze: ISBN 9788087719350.

Fouad, A. A., Rehab, F. M. A. (2015). Effect of germination time on proximate analysis, bioactive compounds and antioxidant activity of lentil (Lens culinaris Medik.) sprouts. Acta Scientiarum Polonorum Technologia Alimentaria, 14(3), 233-246. https://doi.org/10.17306/J.AFS. 2015.3.25

Galchus, R. (2014). Domácí klíčky: podrobný návod k domácímu nakličování po celý rok: luštěniny, obiloviny, výhonky, osení a další. Praha: Slovart. ISBN 978-80-7391-872-9.

ISO 16649-2 (2001). Microbiology of food and animal feeding stuffs Horizontal method for the enumeration of beta-glucuronidase-positive Escherichia coli - Part 2: Colony-count technique at 44 degrees C using 5-bromo-4-chloro-3-indolyl beta-D-glucuronide. Available from: https://www.iso.org/standard/29824.html

ISO 21527-2 (2008). Microbiology of food and animal feeding stuffs Horizontal method for the enumeration of yeasts and moulds Part 2: Colony count technique in products with water activity less than or equal to 0.95. Available from: https://www.iso.org/standard/38276.html

ISO 21528-2 (2018). Microbiology of the food chain - Horizontal method for the detection and enumeration of Enterobacteriaceae - Part 2: Colony-count technique. Available from: https://www.iso.org/ standard/63504.html

Jarpa-Parra, M. (2018). Lentil protein: a review of functional properties and food application. An overview of lentil protein functionality. International Journal of Food Science \& Technology, 53(4), 892-903. https://doi.org/10.1111/ijfs.13685

Jirková, J. (2016). Klíčení semen pro zdraví. Všestary: Jana Jirková - Moje e-kniha. ISBN 978-80-88174-03-5.

Kvasnička, F., Čopíková, J., Ševčík, R., Václavíková, E., Synytsya, A., Vaculová, K., Voldřich, M. (2011). Determination of phytic acid and inositolphosphates in barley. Electrophoresis, 32(9), 1090-1093. https:// doi.org/10.1002/elps.201000578

Ma, Z., Boye, J. I., Hu, X. (2018). Nutritional quality and techno-functional changes in raw, germinated and fermented yellow field pea (Pisum sativum L.) upon pasteurization. LWT-Food Science and technology, 92, 147-154. https://doi.org/10.1016/j.lwt.2018.02.018

Moslem, F., Ghavidl, R. A., Sharifi, A., Esteri, S. H. (2016). Effect of germination on some of the chemical properties and antioxidant activity 
of red lentils. Journal of Innovation in Food Science and Technology [online; cit. 2020-03-27]. ISSN 2251-6476. Available from: https:// www.cabdirect.org/cabdirect/abstract/20173296672

Regulation (EU) No 1169/2011 of the European Parliament and of the Council of 25 October 2011 on the provision of food information to consumers, amending Regulations (EC) No 1924/2006 and (EC) No 1925/2006 of the European Parliament and of the Council, and repealing Commission Directive 87/250/EEC, Council Directive 90/496/EEC, Commission Directive 1999/10/EC, Directive 2000/13/EC of the European Parliament and of the Council, Commission Directives 2002/67/EC and 2008/5/EC and Commission Regulation (EC) No 608/2004 Text with EEA relevance. Available from: https://eur-lex.europa.eu/legal content/EN/ALL/?uri=CELEX\%3A32011R1169

Rusydi, M. R., Azrina, A. (2012). Effect of germination on total phenolic, tannin and phytic acid contents in soy bean and peanut. International Food Research Journal, 19(2), 673-677. Available from: http:// www.ifrj.upm.edu.my/19\%20(02)\%202012/(45)IFRJ-2012\%20 Azrina.pdf
Saratu, A., Matthew, A. (2011). Nutritional composition of raw and processed pinto bean (Phaseolus vulgaris L.) grown in Nigeria. Journal of Food, Agriculture and Environment. 9(3-4), 72-80.

Schoenlechner, R. (2016). Properties of pseudocereals, selected speciality cereals and legumes for food processing with special attention to gluten-free products/Verarbeitungseigenschaften von Pseudogetreide, ausgewählten Spezialitätengetreide und Leguminosen mit speziellem Fokuss auf glutenfreie Produkte, Die Bodenkultur: Journal of Land Management, Food and Environment, 67(4), 239-248. https://doi.org/10.1515/boku-2016-0019

ÚKZUZ (2019): Determination of amino acid content. Uniform working procedures. Central Agricultural Inspection and Testing Institute. National Reference Laboratory. Available only in Czech: http://eagri.cz/public/web/file/246161/_10021._1_Stanoveni_obsahu_aminokyselin_revize3.pdf 